\title{
Analysis of phthalate degradation operon from Arthrobacter sp. 68b
}

\author{
Rūta Stanislauskienè ${ }^{\star}$, \\ Mark Rudenkov, \\ Laimonas Karvelis, \\ Renata Gasparavičiūtè, \\ Rita Meškienè, \\ Vida Časaitè, \\ Rolandas Meškys \\ Department of Molecular \\ Microbiology and Biotechnology, \\ Institute of Biochemistry, \\ Vilnius University, \\ Mokslininku 12, \\ LT-08662 Vilnius, \\ Lithuania
}

Bacterial strain $68 \mathrm{~b}$ was isolated from contaminated soil. According to $16 \mathrm{~S} \mathrm{rDNA}$ analysis it belongs to genus Arthrobacter. This strain is capable to utilise phthalic acid as a sole carbon source. This ability was proved by physiological and biochemical tests. By using resting cells, it was found out that Arthrobacter sp. $68 \mathrm{~b}$ cells could use phthalic acid or convert quinolinic acid if they were pre-grown in the presence of phthalic acid. While analysing the results of a partially sequenced genome, the putative phthalate degradation operon ( $p h t)$ was detected. It consisted of eight genes; seven genes could code the conversion of phthalate to protocatechuate. It was determined that the gene (pehA) of putative phthalate ester hydrolase is located upstream of pht operon. Genes of putative phthalate degradation operon were re-sequenced and their sequences fully corresponded to the de novo sequencing data. The homology search of genes revealed that all gene products are most similar to phthalate degradation proteins from other Arthrobacter spp. strains and confirmed that the strain $68 \mathrm{~b}$ converts phthalate to protocatechuate by 3,4-dioxygenase pathway.

Key words: Arthrobacter sp., phthalic acid, 3,4-phthalate dioxygenase, quinolinic acid

\section{INTRODUCTION}

Phthalate (1,2-dicarboxybenzene) is a key metabolic intermediate in the aerobic degradation of phthalate esters and some polycyclic aromatic hydrocarbons such as pyrene, phenanthrene, fluorene and fluoranthene [1]. Phthalate esters (PEs) are industrial chemicals, widely used as plasticizers for polyvinyl chloride resins and as cellulose coatings. Their industrial application also includes the manufacturing of a variety of consumer and health care products [2]. Due to their widespread use, PEs have been found in sediments, natural waters, soils and aquatic organisms $[2,3]$.

* Corresponding author: E-mail: ruta.stanislauskiene@bchi.vu.lt
The metabolism of PEs by bacteria is considered a major fate of these widespread pollutants. It is believed that the metabolism of PEs is initiated in bacteria by their hydrolysis to phthalate and two alcohols $[4,5]$. Two catabolic pathways have been identified for the aerobic degradation of phthalate (Fig. 1). Gram-negative bacteria (Burkholderia cepacia, Pseudomonas spp.) transform phthalate through oxygenation and dehydrogenation at carbons 4 and 5 to form 4,5-dihydroxyphthalate, followed by decarboxylation to yield protocatechuate, while gram-positive bacteria ( $A r$ throbacter keyseri, Rhodococcus spp., Terrabacter spp., Mycobacterium vanbaalenii) initially oxidize phthalate to 3,4dihydro-3,4-dihydroxyphthalate (phthalate dihydrodiol), which is subsequently dehydrogenated and decarboxylated to form protocatechuate $[1,4]$. 


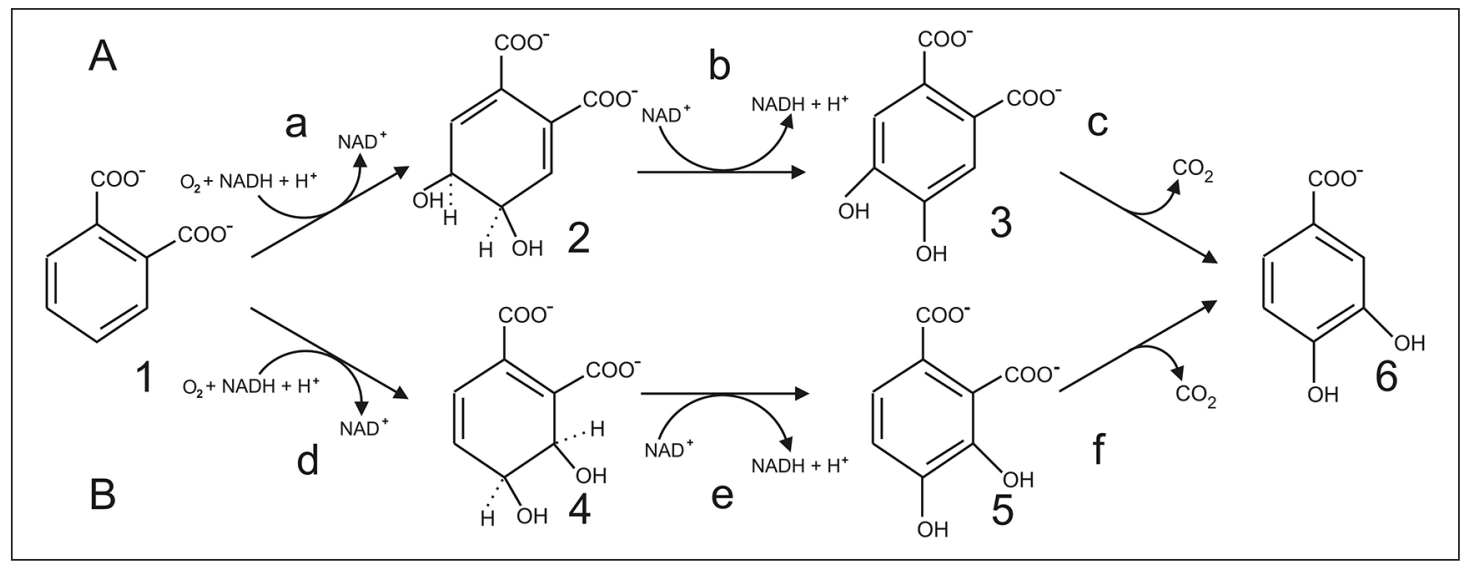

Fig. 1. General pathways for the initial degradation of phthalate by Gram-positive (A) and Gram-negative (B) bacteria. Chemical designations: (1) phthalate; (2) cis-4,5-dihydroxy-4,5-dihydrophthalate; (3) 4,5dihydroxyphthalate; (4) cis-3,4-dihydroxy-3,4-dihydrophthalate; (5) 3,4-dihydroxyphthalate; (6) protocatechuate. Enzymes: (a) phthalate 4,5-dioxygenase; (b) cis-4,5-dihydroxy-4,5-dihydrophthalate dehydrogenase; (c) 4,5-dihydroxyphthalate-2-decarboxylase; (d) phthalate3,4-dioxygenase; (e) cis-3,4dihydroxy-3,4-dihydrophthalate dehydrogenase; (f) 3,4-dihydroxyphthalate-2-decarboxylase

The genus Arthrobacter are gram-positive, aerobic, nonmotile soil bacteria that occur in a wide variety of environmental niches. Phylogenetically the genus belongs to a group of GC-rich bacteria within the order of Actinomycetales that includes Gordonia, Nocardia, Mycobacterium, Rhodococcus. Various strains of Arthrobacter genus are able to gain energy from the degradation of a large variety of natural or man-made organic compounds present in their surroundings; therefore, they do not need any growth factors [6]. Recently, these microorganisms have received considerable attention because of their potential use in pesticides, aromatic and $\mathrm{N}$-heterocyclic compounds and other industrial product waste detoxification. It has been shown that Arthrobacter spp. bacteria are capable of degrading nicotine [7], nitrophenols [8,9], phtalates [4], carbaryl [10], atrazine [11, 12], phenmedipham [13], duron [14], pyridines [15-17] and other compounds.

To date, several microorganisms belonging to Arthrobacter spp. and capable to degrade phthalate are known. Arthrobacter keyseri 12B harbour the plasmid pRE1 which encodes a complete catabolism of phthalate [4]. Recently, Arthrobacter sp. strain WY capable to utilize butyl benzyl phthalate as well as phthalic and protocatechuic acids as sole carbon and energy source has been described [2].

At present, there are increasing demands for new chemical products that are used in environmentally friendly technologies and adopt sustainable approaches. These are driving the search for new biocatalysts for the development of new bioprocesses. Environmental microbes are considered to be the main source of new enzymatic activities owing to their enormous metabolic capability and diversity, much of which currently remains unexplored [18]. The new range of enzymes, especially the ones involved in various biodegradation pathways and enantiopure bioproducts, including di-, tri- and tetra-oxygenated metabolites resulting from tandem dioxygenase-catalysed oxidations of arene substrates, open exciting possibilities for the synthesis of new compounds $[19,20]$.

Various $N$-heterocyclic compounds and their derivatives are converted into useful chemicals by microbial or enzymatic oxidation [21-25]. It is known that cells of a Pseudomonas putida strain adapted for phthalate could convert 2,3-dicarboxypyridine (quinolinic acid) to a hydroxylated product. Phthalate 4,5-dioxygenase and 4,5-dihydro-4,5-dihydroxyphthalate dehydrogenase are involved in the initial steps of phthalate degradation by this bacteria [26]. However, it is not shown that quinolinic acid could be converted by the microorganisms possesing the phthalate 3,4-dioxygenase.

In this study, Arthrobacter sp. 68b strain, utilizing phthalate as a sole carbon and energy source by phthalate 3,4dioxygenase pathway, is described. Details on the phthalate degradation operon from this bacteria and data on the bioconversion of 2,3-dicarboxypyridine (quinolinic acid) by phthalate-induced Arthrobacter sp. $68 \mathrm{~b}$ cells are presented.

\section{MATERIALS AND METHODS}

Bacterial strains and plasmids. Bacterial strains Escherichia coli DH5 $\alpha$ (F- ( $\varphi 80 d \Delta$ (lacZ)M15) recA1 endA1 gyrA96 thil hsdR17 (rk-mk+) supE44 relA1 deoR $\Delta$ (lacZYA-argF) U169 (Pharmacia)) and Arthrobacter sp. 68b (capable to utilize phthalic acid as a sole carbon and energy source (laboratory strain)) were used in this study. Plasmid 
pTZ57R/T (Ap ${ }^{\mathrm{R}}$, lacZ, f1, $2.9 \mathrm{~kb}, 3$ '-ddT overhangs at both ends (JSC "Fermentas", Lithuania)) was used for fragment cloning and sequencing.

E. coli $\mathrm{DH} 5$ a bacteria were cultivated on NA (nutrient agar $28 \mathrm{~g} / \mathrm{L}$ ) (Oxoid) plates at $37^{\circ} \mathrm{C}$ or in $\mathrm{NB}$ (nutrient broth $13 \mathrm{~g} / \mathrm{L}$ ) (Oxoid) aerobically at $30^{\circ} \mathrm{C}$. Ampicillin (Fluka) was added to the media at the final concentrations of $50 \mu \mathrm{g} / \mathrm{ml}$. X-Gal and IPTG (JSC "Fermentas", Lithuania) were used at $10 \mathrm{mM}$ final concentration. Arthrobacter sp. $68 \mathrm{~b}$ bacteria were grown in mineral media EFA $(10 \mathrm{~g} / \mathrm{L}$ $\mathrm{K}_{2} \mathrm{HPO}_{4}, 4.0 \mathrm{~g} / \mathrm{L} \mathrm{KH}_{2} \mathrm{PO}_{4}, 1.0 \mathrm{~g} / \mathrm{L}\left(\mathrm{NH}_{4}\right)_{2} \mathrm{SO}_{4}, 0.5 \mathrm{~g} / \mathrm{L}$ yeast extract, $0.4 \mathrm{~g} / \mathrm{L} \mathrm{MgSO}_{4} \times 7 \mathrm{H}_{2} \mathrm{O}, 10 \mathrm{ml} / \mathrm{L}$ salt solution $\left(2.0 \mathrm{~g} / \mathrm{L} \mathrm{CaCl} \times 2 \mathrm{H}_{2} \mathrm{O}, 1.0 \mathrm{~g} / \mathrm{L} \mathrm{MnSO}_{4} \times 4 \mathrm{H}_{2} \mathrm{O}, 0.5 \mathrm{~g} / \mathrm{L}\right.$ $\mathrm{FeSO}_{4} \times 7 \mathrm{H}_{2} \mathrm{O}$ dissolved in $\left.0.1 \mathrm{~N} \mathrm{HCl}\right)$ ) at $30{ }^{\circ} \mathrm{C}$ with shaking $(180 \mathrm{rpm})$ or on EFA agar plates at $30^{\circ} \mathrm{C}$.

Evaluation of optimal phthalic acid growth concentration. To perform the growth curves, $1 \mathrm{~mL}$ of Arthrobacter sp. $68 \mathrm{~b}$ bacteria night culture was transferred to $20 \mathrm{~mL}$ of mineral media EFA containing $0.1-1 \%$ of phthalic acid. Media without carbon source was used as control. Optical density was measured by spectrophotometer at $600 \mathrm{~nm}$ length wave in the cuvette of $1 \mathrm{~cm}$ width every 24 hours.

DNA isolation and manipulation. Total DNA from $\mathrm{Ar}$ throbacter $\mathrm{sp} .68 \mathrm{~b}$ was isolated by the method proposed by Woo et al. [27]. Plasmid DNA from E. coli was isolated by the alkaline lysis method [28]. Restriction endonucleases, phosphotase (FastAP), T4 DNA ligase were purchased from "Fermentas" (Lithuania) and used as recommended. DNA for sequencing was purified using ZYMO Plasmid MiniPREP (Zymo Research). E. coli cells were prepared for electroporation by the method of Sharma \& Schimke [29]. Electroporation into $100 \mu \mathrm{l}$ of the cells was performed using the electroporator 2510 (Eppendorf, Germany) with the electrical conditions selected as $2.0 \mathrm{kV} / \mathrm{cm}$ and impulse duration of 5.0-5.6 ms. Transformed E. coli bacteria were incubated at $37^{\circ} \mathrm{C}$ for 1 hour, thereafter cells were spread on solid NA with ampicillin.

DNA sequencing and analysis. Total DNA from Arthrobacter sp. 68b was applied for 454 pyrosequencing (Macrogen, South Korea). The BLAST software was used for the analysis of contigs [30]. Primers for phthalic acid degradation operon genes were designed using DNA from a partially sequenced genome (Table 1). PCR products were cloned in pTZ57R/T and re-sequenced using standard sequencing primers M13 ( $\mathrm{R}$ and F). 16S rRNA encoding gene (1.5 kb fragment) was amplified using universal primers w001 and w002. The PCR product was purified with a DNA purification kit and cloned into a pTZ57R/ T plasmid. The sequencing was performed at Macrogen (South Korea). VectorNTI 9.0 [31] was used for the DNA and protein analysis. The nearest homologues for the phylogenetic analysis of proteins were picked by using the BLAST family programmes (NCBI) [30]. The evolutionary history was inferred using the neighbour-joining method [32]. The evolutionary distances were computed using the Poisson correction method [33] and were found in the units of the number of amino acid substitutions per site. The phylogenetic analyses were carried out by MEGA 5 [34].

Detection of phthalate 4,5-dioxygenase activity. To detect phthalate 4,5-dioxygenase activity, a diazotized $p$ nitroaniline was used as described by Nomura et al. [26]. The reagent was prepared by mixing 50 volumes of a $0.3 \%$ $(\mathrm{w} / \mathrm{v})$ solution of $p$-nitroaniline in $0.8 \mathrm{~N} \mathrm{HCl}$ and 3 volumes of a $5 \% \mathrm{NaNO}_{2}$ solution immediately before use. Arthrobacter sp. $68 \mathrm{~b}$ bacteria were cultivated 48 hours in EFA medium containing $0.5 \%$ phthalic acid at $30{ }^{\circ} \mathrm{C}$ by shaking. Cells were harvested and washed with $20 \mathrm{mM}$ Tris- $\mathrm{HCl}$ buffer ( $\mathrm{pH} \mathrm{8.0)}$ and suspended in the same buffer containing $2.5 \mathrm{mM}$ of quinolinic acid. The cell suspension was incubated at $30{ }^{\circ} \mathrm{C}$ and the samples were taken after 1 and 2 hours. Cells were eliminated by centrifugation and the supernatant was added with $2 \mu \mathrm{L}$ of diazotized $p$-nitroaniline reagent per $\mathrm{mL}$. The absorption spectrum was read over the range of 300 to $700 \mathrm{~nm}$.

Resting cell reaction. Cells were grown in $20 \mathrm{~mL}$ of EFA containing $0.5 \%$ phthalic acid for 48 hours, harvested at $10{ }^{\circ} \mathrm{C}$ by centrifugation at $3.220 \mathrm{~g}$ for $10 \mathrm{~min}$, washed two times with $20 \mathrm{mM}$ potassium phosphate buffer ( $\mathrm{pH} 7.5$ ), suspended in $10 \mathrm{~mL}$ and used as the resting cells. Cells from $1.5 \mathrm{~mL}$ culture broth were incubated in $20 \mathrm{mM}$

Table 1. Primers used for the amplification of phthalate degradation and pehA genes

\begin{tabular}{cc}
\hline Primer name, amplified region & Primer sequence \\
\hline FEH (F) phthalic ester hydrolase & gacatccgaacagtttaggaagagg \\
\hline FEH (R) phthalic ester hydrolase & gtatatctaggcgggcatctctag \\
\hline HFDH (F) 3,4-dihydroxy-3,4-dihidrophthalate dehidrogenase & ctagagatgcccgcctagatatac \\
\hline HFDH (R) 3,4-dihydroxy-3,4-dihidrophthalate dehidrogenase & ggttctggtatgaagagaatgga \\
\hline FOXG (F) phthalate dioxygenase large and small subunits & gagatccgtccatgactgaccac \\
\hline FOXG (R) phthalate dioxygenase large and small subunits & gtcctcttcttcgccttcccatt \\
\hline FOXGS (F) ferredoxin and reductase subunits & gaggacgagcagtcgccccagaaca \\
\hline FOXGS (R) ferredoxin and reductase subunits & ctgcctttgctcttcgtgggccac \\
\hline FDK (F) 3,4-dihidroxyphthalate-2-decarboxylase & cagcgtgcaggaactccgggacaaac \\
\hline FDK (R) 3,4-dihidroxyphthalate-2-decarboxylase & cgcatgctttgtatcgtacccagcg
\end{tabular}


potassium phosphate buffer $(\mathrm{pH} 7.5)$ with an appropriate dicarboxylic acid in a $1 \mathrm{~mL}$ reaction mixture. The reaction was carried out in an orbital shaker $(350 \mathrm{rpm})$ at $30^{\circ} \mathrm{C}$ temperature.

The nucleotide sequences. The nucleotide sequences, determined in this study, were deposited in the EMBL-Bank under the accession numbers AJ879122 (16S rDNA) and JN381019 (pht operon).

\section{RESULTS}

The $68 \mathrm{~b}$ strain was isolated from the contaminated soil. The analysis of $16 \mathrm{~S}$ rDNA sequence revealed that it belonged to the genus Arthrobacter. The partial sequencing of the Arthrobacter sp. $68 \mathrm{~b}$ genome was carried out. While analysing the sequencing results, the putative phthalate degradation operon was detected. To confirm the de novo sequencing data, a set of primers was chosen according to the DNA sequence (Table 1). All PCR reactions using these primer pairs and total DNA from Arthrobacter sp. $68 \mathrm{~b}$ were positive (data not shown). Moreover, the amplified DNA fragments were re-sequenced and their sequences fully corresponded to the de novo sequencing data.

The ability to utilize phthalic acid was proved by cultivating bacteria on media containing phthalic acid as a sole carbon source (Fig. 2). The optimal phthalic acid growth concentration for Arthrobacter sp. 68b was determined as described in "Materials and methods". The best bacteria growth after 24 hours was observed when phthalic acid concentrations ranged from $0.5-1 \%$ (Fig. 2). After 72 hours, the decrease of optical density was observed in all cultures. Bioconversion of phthalic acid by resting cells was additionally analysed to confirm that cells of Arthrobacter sp. 68b could consume this substrate (Fig. 3). It was found that $A r$ throbacter sp. 68b cells could use phthalic acid only if they were pre-grown in the presence of this substrate (Fig. 3, B).
The cells cultivated in the presence of succinic acid were not able to consume phthalic acid (Fig. 3, A). Hence, phthalate utilization is an inducible process in the Arthrobacter sp. $68 \mathrm{~b}$ cells.

A more detailed analysis of the phthalate degradation operon (pht) from Arthrobacter sp. 68b showed that it consisted of eight open reading frames (ORF) (Fig. 2, Table 2), all transcribed in the same direction. Seven genes arranged in the order phtBAaAbAcAdCR could code the conversion of phthalate to protocatechuate by 3,4-dioxygenase pathway (Fig. 1, B).

Comparison of the organization of genes, involved in phthalate metabolism in Arthrobacter sp. 68b and Arthrobacter keyseri $12 \mathrm{~B}$, revealed that the genes of both operons are arranged in the same order and transcribed in the same direction (Fig. 4). However, Arthrobacter sp. 68b operon has an additional gene orf4 that is inserted between the genes

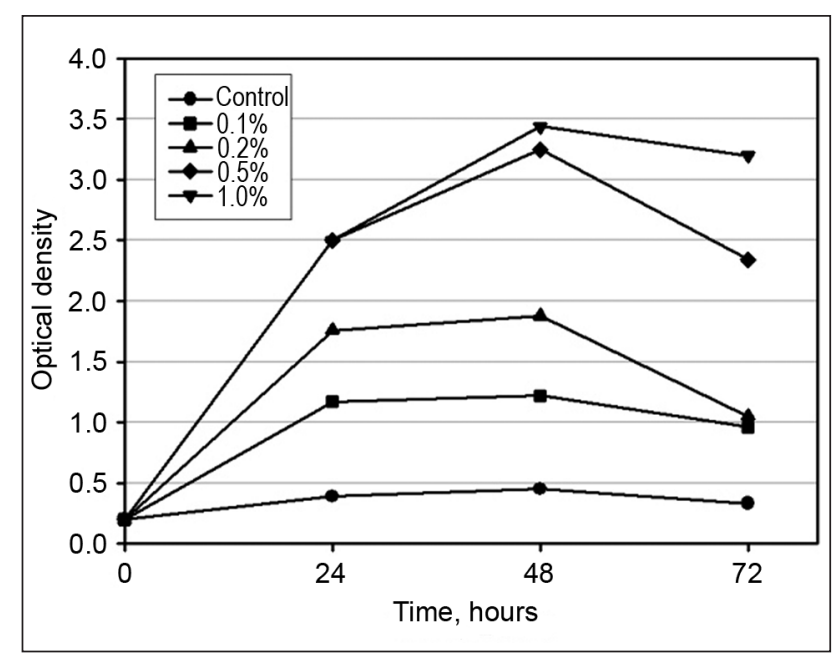

Fig. 2. Growth of Arthrobacter sp. 68b in EFA medium containing various concentrations of phthalic acid. Control EFA medium without phthalic acid

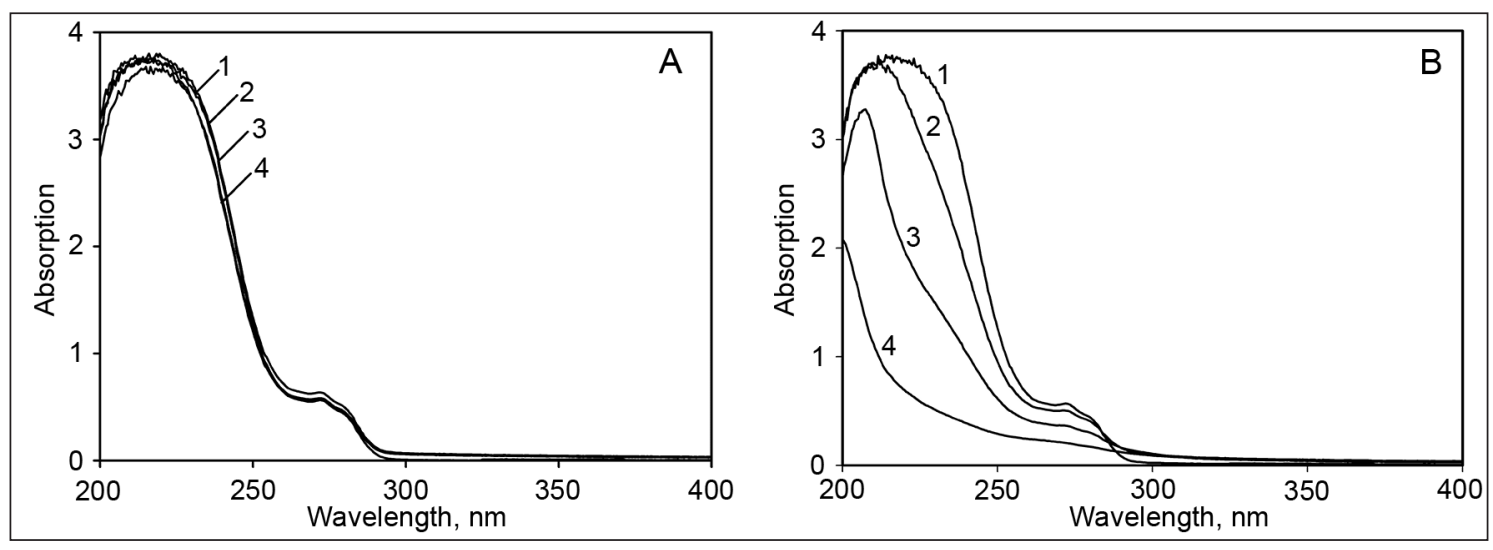

Fig. 3. Spectral changes during aerobic conversion of phthalic acid by resting cells of Arthrobacter sp. $68 \mathrm{~b}$ pre-grown with succinate (A) and phthalic acid (B) in $20 \mathrm{mM}$ potassium phosphate buffer $(\mathrm{pH} 7.5)$ at $30^{\circ} \mathrm{C}$. Initial substrate concentration was $1 \mathrm{mM}$. The reaction mixture after centrifugation $(16.000 \times \mathrm{g}, 1 \mathrm{~min})$ was scanned at 1, 2, 3, 4 hours 
Table 2. Genes and gene products

\begin{tabular}{|c|c|c|c|c|c|c|}
\hline ORF & Gene & $\begin{array}{l}\text { Protein } \\
\text { length (aa) }\end{array}$ & Homology & $\begin{array}{c}\text { GenBank accession } \\
\text { No. } \\
\end{array}$ & E value & Reference \\
\hline ORF1 & phtB & 287 & $\begin{array}{l}\text { 3,4-dihydroxy-3,4-dihydrophthalate } \\
\text { dehydrogenase, Arthrobacter keyseri }\end{array}$ & AF331043_13 & $8 e-126$ & {$[4]$} \\
\hline ORF2 & phtAa & 474 & $\begin{array}{c}\text { phthalate dioxygenase large subunit, } \\
\text { Arthrobacter keyseri }\end{array}$ & AF331043_14 & 0 & [4] \\
\hline ORF3 & $p h t A b$ & 202 & $\begin{array}{c}\text { phthalate 3,4-dioxygenase subunit } \\
\text { beta, Arthrobacter phenanthrenivorans } \\
\text { Sphe3 }\end{array}$ & YP_004243272 & $5 e-97$ & [38] \\
\hline ORF4 & orf4 & 111 & $\begin{array}{l}\text { hypothetical protein Arth_4365, Arthro- } \\
\text { bacter sp. FB24 }\end{array}$ & YP_829383 & $5 e-46$ & Unpublished \\
\hline ORF5 & phtAc & 65 & $\begin{array}{l}\text { ferredoxin, Arthrobacter phe- } \\
\text { nanthrenivorans Sphe3 }\end{array}$ & YP_004243274 & $1 e-24$ & [38] \\
\hline ORF6 & phtAd & 411 & $\begin{array}{l}\text { phthalate 3,4-dioxygenase, ferredoxin } \\
\text { reductase subunit, Arthrobacter phen- } \\
\text { anthrenivorans Sphe3 }\end{array}$ & YP_004243275 & 0 & {$[38]$} \\
\hline ORF7 & phtC & 249 & $\begin{array}{l}\text { 3,4-dihydroxyphthalate decarboxylase, } \\
\text { Arthrobacter phenanthrenivorans Sphe3 }\end{array}$ & YP_004243276 & $7 e-111$ & [38] \\
\hline ORF8 & phtR & 264 & $\begin{array}{l}\text { PhtR family transcriptional regulator, } \\
\text { Arthrobacter phenanthrenivorans Sphe3 }\end{array}$ & YP_004243277 & $3 e-121$ & [38] \\
\hline
\end{tabular}

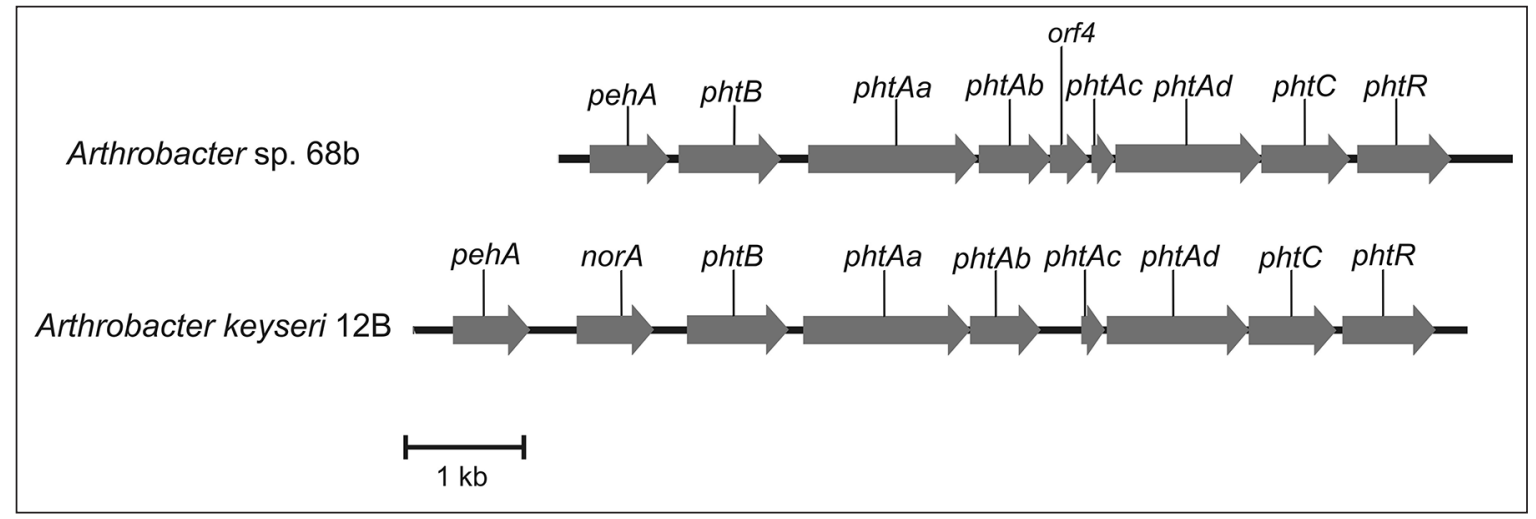

Fig. 4. Phthalate degradation operons and the organization of genes in Arthrobacter sp. 68b and Arthrobacter keyseri 12B

$p h t A b$ and $p h t A c$. The orf4 overlaps with the gene phtAb by four nucleotides, while the start codons of genes $p h t C$ and phtAd overlap with the stop codon of the preceding gene by one nucleotide. The gene pehA, encoding a putative phthalate ester hydrolase, is located upstream of pht operon in both cases. This gene is transcribed in the same direction as genes of phthalate degradation operon. An additional gene (norA, a fragment of antibiotic resistance transporter) is located between the gene pehA and pht operon in the case of A. keyseri 12B, however, none homologous gene was found in Arthrobacter sp. 68b.

As the organization of both operons was similar, genes of the phthalate operon from Arthrobacter sp. $68 \mathrm{~b}$ were named in the manner of those of A. keyseri 12B. The homology search of genes revealed that all gene products were most similar to the phthalate degradation proteins from other Arthrobacter spp. strains (Table 2). The genes phtAaAbAcAd encode a phthalate 3,4-dioxygenase. Gene phtAa encodes protein $(53.7 \mathrm{kDa})$ that is most homologous to A. keyseri 12B phthalate dioxygenase large subunit. The most similar proteins are phthalate 3,4-dioxygenase large subunits or ring hydroxylating dioxygenase alpha subunits generally from Rhodococcus sp. and Mycobacterium sp. Arthrobacter sp. $68 \mathrm{~b}$ phtAa product together with A. keyseri 12B and Arthrobacter sp. FB24 proteins make a discrete group in the phylogenetic tree (Fig. 5, A). The product $(22.8 \mathrm{kDa})$ of gene $p h t A b$ is analogous to the phthalate 3,4-dioxygenase subunit beta or a small subunit and the 3-phenylpropionate dioxygenase subunit beta from various Arthrobacter sp., Rhodococcus sp. and Mycobacterium sp. strains. As the phylogenetic tree presents the Arthrobacter sp. 68b protein, it shares the same branch with the proteins from Arthrobacter sp. FB24, A. keyseri $12 \mathrm{~B}$ and A. phenanthrenivorans Sphe3 (Fig. 5, B). The phtAc polypeptide $(7.0 \mathrm{kDa})$ is related to the electron transfer protein ferredoxin. Its homologues are proteins from various Actinomycetales bacteria species. 


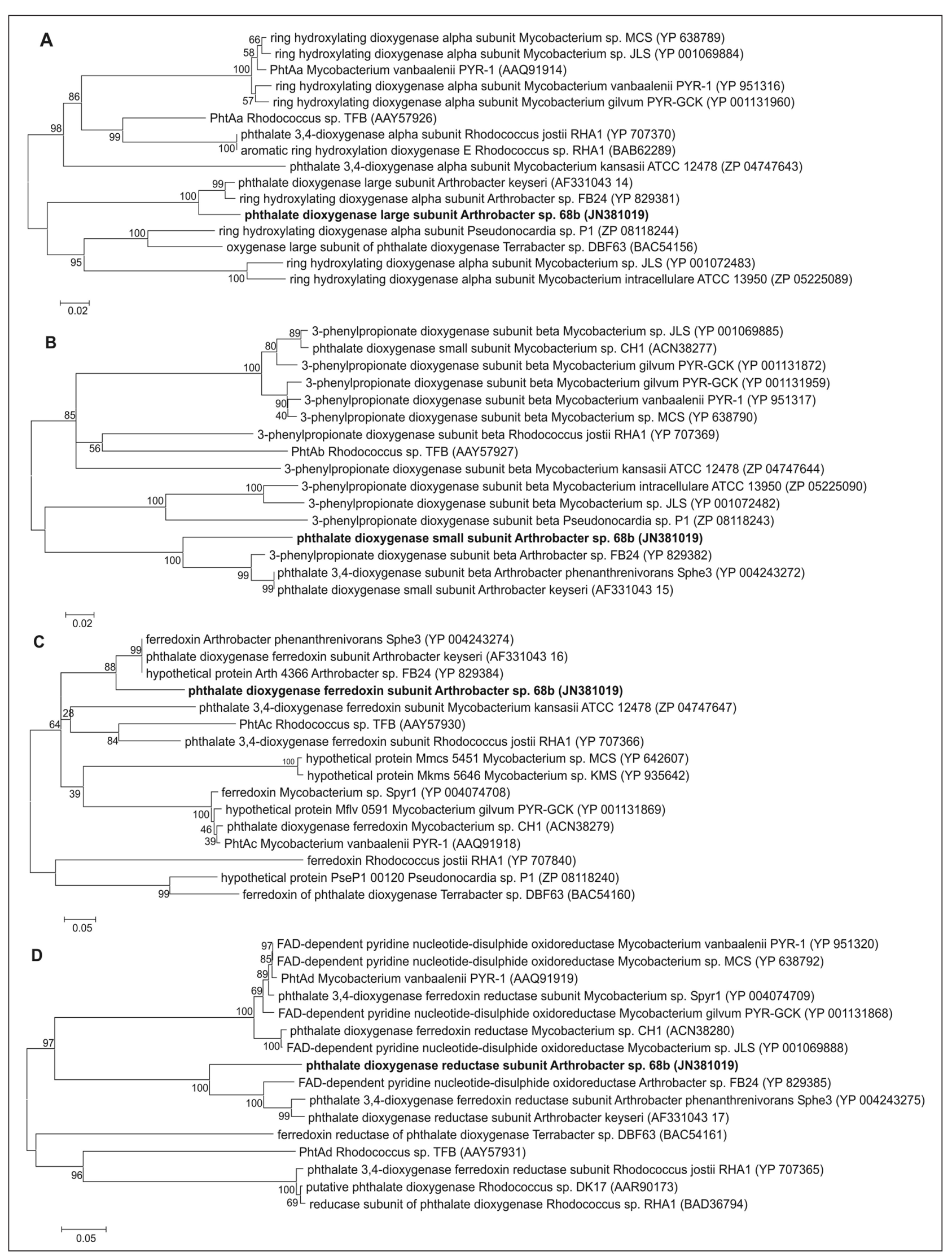

Fig. 5. The phylogenetic tree of phthalate 3,4-dioxygenase from Arthrobacter sp. 68b. A - large subunit, B - small subunit, C - ferredoxin subunit, $D$ - reductase subunit. The numbers at the branches show how many times the group to the right of the branch occurred among the 100 trees generated in a bootstrap analysis. Scale bar represents the expected amino acid substitutions per position. The GenBank accession number is indicated for each protein. Details of phylogenetic method are given in Materials and methods 


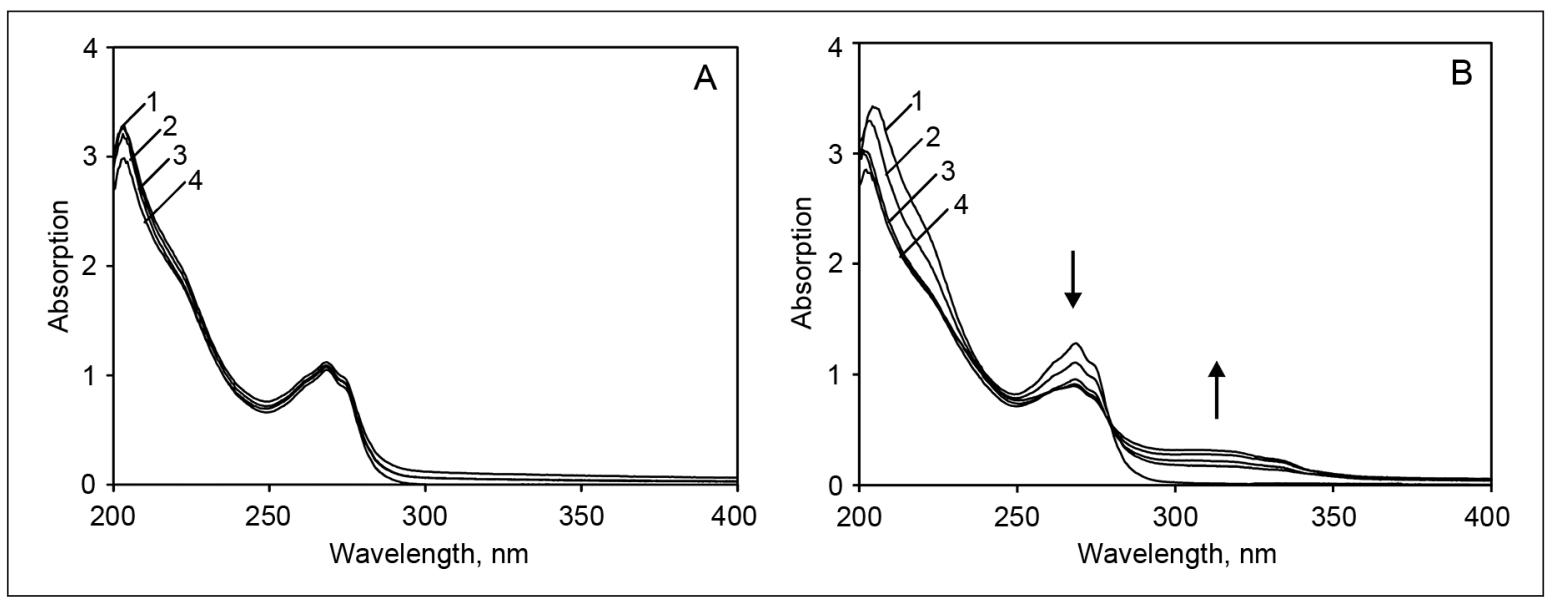

Fig. 6. Spectral changes during aerobic conversion of quinolinic acid by resting cells of Arthrobacter sp. $68 \mathrm{~b}$ pre-grown with succinate $(\mathrm{A})$ and phthalic acid (B) in $20 \mathrm{mM}$ potassium phosphate buffer ( $\mathrm{pH} 7.5$ ) at $30^{\circ} \mathrm{C}$. Initial substrate concentration was $0.4 \mathrm{mM}$. The reaction mixture after centrifugation $(16.000 \times \mathrm{g}$, $1 \mathrm{~min}$ ) was scanned at 1, 2, 3, 4 hours. Arrows show changes in absorption during bioconversion

PhtAc is the most similar to proteins from Arthrobacter sp. FB24, A. keyseri 12B and A. phenanthrenivorans Sphe3. Together, they make a discrete branch in the phylogenetic tree (Fig. 5, C). The phtAd encoded protein $(43.7 \mathrm{kDa})$ is similar to the phthalate 3,4-dioxygenase ferredoxin reductase subunit, FAD-dependent pyridine nucleotide-disulphide oxidoreductase. The phylogenetic analysis of the protein revealed that it is most related to the proteins from Arthrobacter spp. and form together a separate phylogenetic branch (Fig. 5, D).

The pht $B$ product $(31.3 \mathrm{kDa})$ is homologous to aldo/ keto reductases, 2,5-didehydrogluconate reductases, 2,5diketo-D-gluconate reductases and oxidoreductases from various Actinomycetales bacteria and several proteobacteria. PhtB is the most similar to 3,4-dihydroxy-3,4-dihydrophthalate dehydrogenase from A. keyseri 12B. The product $(26.2 \mathrm{kDa})$ of phtC is homologous to 3,4-dihydroxyphthalate decarboxylase, class II aldolase / adducin family protein from Arthrobacter spp., Rhodococcus spp. and Mycobacterium spp. phtR encodes $29.2 \mathrm{kDa}$ protein that is similar to the transcriptional regulators of PhtR or IclR families from Actinomycetales bacteria. In the $\mathrm{N}$-terminus of PhtR protein, a HTH motif was detected. It is typical to IclR family proteins that can act as a transcriptional activators or repressors.

It was known that cells of a Pseudomonas putida strain, harbouring both phthalate 4,5-dioxygenase and 4,5-dihydro-4,5-dihydroxyphthalate dehydrogenase and adapted for phthalic acid, could also convert quinolinic acid to a hydroxylated product [26]. The formation of this compound was visualized by the reaction with diazotized $p$-nitroaniline with which a red compound with the absorbtion maximum at $512 \mathrm{~nm}$ was produced [26]. The phthalic acid induced cells of Arthrobacter sp. 68b were tested on their ability to form a similar product under the same conditions, however, no formation of the red compound was observed. Bioconversion of quinolinic acid by resting cells was tested to determine if phthalate-induced cells of Arthrobacter sp. 68b could consume quinolinic acid. It was found that Arthrobacter sp. 68b cells converted quinolinic acid if they were pre-grown in the presence of phthalic acid. The changes in the UV-VIS spectrum during a typical biotransformation are illustrated in Fig. 6 (B). The cells, cultivated in the presence of succinic acid, were not able to use quinolinic acid (Fig. 6, A). Hence, an induction of phthalate catabolic genes was necessary for the utilization of quinolinic acid by $A r$ throbacter sp. 68b cells. Moreover, the absorbance increase in the region $300-350 \mathrm{~nm}$ during the bioconversion procedure was observed.

\section{DISCUSSION}

Partial de novo sequencing of Arthrobacter sp. 68b genome shows that this microorganism harbours the genes encoding phthalic acid degradation. The organization of genes in Arthrobacter sp. 68b and A. keyseri 12B phthalate degradation operons is similar, though it differs from the organizations of pht operons in other Actinomycetales, for example, phthalate degradation genes are arranged in order phtRAaAbBAcAdC in Rhodococcus sp. DK17 [35] and Rhodococcus sp. TFB [36] strains. The decarboxylase encoding gene is not presented in pht operon of Mycobacterium vanbaalenii PYR-1, hence, genes are set in phtRAaAbBAcAd order [37]. All genes of the operons are transcribed in the same direction, except the regulatory protein gene $(p h t R)$, which is located upstream of the operon and is transcribed from the opposite strand in these strains [35-37]. Phylogenetic analysis of pht genes 
encoding proteins shows that Arthrobacter sp. 68b biodegradation of phthalic acid has to proceed through the 3,4dioxygenation step (Fig. 1, B).

Physiological and biochemical tests confirm the capability of Arthrobacter sp. 68b to utilize phthalic acid. Moreover, that is an inducible process.

It should be noted that the phthalate degradation genes of A. keyseri 12B are situated on the plasmid pRE1 and form an operon [4]. Arthrobacter phenanthrenivorans Sphe3 plasmid pASPHE301 contains genes that could be involved in phthalate degradation [38]. The previous findings that phthalic acid degradation genes in various Actinomycetales (Arthrobacter and Rhodococcus spp.) are plasmid located $[35,36,39]$ raise the question if a catabolic plasmid encoding analogous genes exist in Arthrobacter sp. 68b cells. Further experiments have to be carried out to elucidate this possibility.

Bioconversion of quinolinic acid by phthalate induced Arthrobacter sp. 68b cells is rather interesting, since it is generally believed that only phthalate 4,5-dioxygenase and 4,5-dihydro-4,5-dihydroxyphthalate dehydrogenase harbouring microorganisms are capable of such transformation [26]. During the quinolinic acid biotransformation by resting Arthrobacter sp. 68b cells, the UV absorption maximum shifted into the longer wavelength area (Fig. 6, B), indicating the introduction of a hydroxyl group into the heterocyclic ring [40]. There are several possibilities to form the hydroxylated derivatives of quinolinic acid. The first, quinolinic acid is initially attacked by phthalate 3,4-dioxygenase. Then, the 4,5-dihydroxy-4,5-dihydroquinolinic acid is oxidized by 3,4-dihydroxy-3,4-dihydrophthalate dehydrogenase to 4,5-dihydroxyquinolinic acid. The second, quinolinic acid is initially attacked by phthalate 3,4-dioxygenase. Then, the 4,5-dihydroxy-4,5-dihydroquinolinic acid is spontaneously dehydrated to 4 -hydroxy or 5-hydroxyquinolinic acid. The products of both, either the first or the second bioconversions, are promising as synthons, since they are not easily obtainable by the known methods of organic chemistry. However, further experiments have to be carried out to determine the structure of the formed compound.

Concluding, it has to be noted that a new phthalate degrading microorganism belonging to Arthrobacter genus is characterized. Bioconversion of quinolinic acid by $68 \mathrm{~b}$ strain bacteria opens a possibility for biocatalytic synthesis of new hydroxylated $N$-heterocyclic compounds.

\section{ACKNOWLEDGEMENTS}

This research was funded by a grant (No. MIP-076/2011) from the Research Council of Lithuania.

Received 5 August 2011 Accepted 22 September 2011

\section{References}

1. Choi KY, Kim D, Chae J-C, Zylstra GJ, Kim E. Requirement of duplicated operons for maximal metabolism of phthalate by Rhodococcus sp. strain DK17. Biochem Biophys Res Commun 2007; 357: 766-71.

2. Chatterjee S, Dutta TK. Complete degradation of butyl benzyl phthalate by a defined bacterial consortium: Role of individual isolates in the assimilation pathway. Chemosphere 2008; 70: 933-41.

3. Chatterjee S, Karlovsky P. Removal of the endocrine disrupter butyl benzyl phthalate from the environment. Appl Microbiol Biotechnol 2010; 87: 61-73.

4. Eaton RW. Plasmid-encoded phthalate catabolic pathway in Arthrobacter keyseri 12B. J Bacteriol 2001; 183: 3689-703.

5. Hara H, Stewart GR, Mohn WW. Involvement of a novel ABC transporter and monoalkyl phthalate ester hydrolase in phthalate ester catabolism by Rhodococcus jostii RHA1. Appl Environ Microbiol 2010; 1516-23.

6. Jones D, Keddie RM. The genus Arthrobacter. In The Prokaryotes, 2nd edition. Edited by Balows A., Trüper HG, Dworkin M, Harder W, Schleifer K.-H. Volume II, 1992, Springer-Verlag.

7. Igloi GL, Brandsch R. Sequence of the 165-kilobase catabolic plasmid pAO1 from Arthrobacter nicotinovorans and identification of a pAO1-dependent nikotine uptake system. J Bacteriol 2003; 185: 1976-86.

8. Hanne LF, Kirk LL, Appel SM Narayan AD, Bains KK. Degradation and induction specificity in Actinomycetes that degrade $p$-nitrophenol. Appl Environ Microbiol 1993; 59: 3505-8.

9. Chauhan A, Chakraborti AK, Jain RK. Plasmid-encoded degradation of $p$-nitrophenol and 4-nitrocatechol by Arthrobacter protophormiae. Biochem Biophys Res Commun 2000; 270: 733-40.

10. Hayatsu M, Hirado M, Nagata T. Involvement of two plasmids in the degradation of carbaryl by Arthrobacter sp. strain RC100. Appl Environ Microbiol 1999; 65: 1015-9.

11. Rousseaux S, Soulas G, Hartmann A. Plasmid localisation of atramine-degrading genes in newly described Chelatobacter and Arthrobacter strains. FEMS Microbiol Ecol 2002; 41: 69-75.

12. Sajjaphan K, Shapir N, Wackett LP, Palmer M, Blackmon B, Tomkins J, Sadowsky MJ. Arthrobacter aurescens $\mathrm{TC} 1$ atrazine catabolism genes $\operatorname{tr} z \mathrm{~N}$, atzB and $a t z C$ are linked on a 160-kilobase region and are functional in Escherichia coli. Appl Environ Microbiol 2004; 70: 4402-7.

13. Pohlenz HD, Boidol W, Schüttke I, Streber WR. Purification and properties of an Arthrobacter oxydans P52 carbamate hydrolase specific for the herbicide phenme- 
dipham and nucleotide sequence of the corresponding gene. J Bacteriol 1992; 174: 6600-7.

14. Turnbull GA, Ousley M, Walker A, Shaw E, Morgan JAW. Degradation of substituted phenylurea herbicides by Arthrobacter globiformis strain D47 and characterization of a plasmid-associated hydrolase gene, puhA. Appl Environ Microbiol 2001; 67: 2270-5.

15. Bondareva A, Marcinkevičienè L, Bachmatova I, Semènaitė R, Meškienė R, Meškys R. Plasmid-mediated degradation of 2-hydroxypyridine by a gram-positive bacterium. Biologija 2000; (1): 22-4.

16. Semènaitè R, Duran R, Marcinkevičienè L, Bachmatova I, Pacenkaitė J, Časaitè V, Gasparavičiūtè R, Trainys M, Meškys R. Degradation of pyridine and 2-hydroxypyridine by environmental Rhodococcus and Arthrobacter strains. Biologija 2000; (2): 329-31.

17. Semènaitė R, Gasparavičiūtė R, Duran R, Precigou S, Marcinkevičienė L, Bachmatova I, Meškys R. Genetic diversity of 2-hydroxypyridine-degrading soil bacteria. Biologija 2003; (2): 27-9.

18. Singh BK. Exploring microbial diversity for biotechnology: the way forward. Trends Biotechnol 2010; 28 : 111-6.

19. Boyd DR, Sharma ND, Allen CCR. Aromatic dioxygenases: molecular biocatalysis and applications. Curr Opin Biotechnol 2001; 12: 564-73.

20. Li Z, van Beilen JB, Duetz WA, Schmid A, de Raadt A, Griengl H, Witholt B. Oxidative biotransformations using oxygenases. Curr Opin Chem Biol 2002; 6: 13644.

21. Hurh B, Ohshima M, Yamane T, Nagasawa T. Microbial production of 6-hydroxynicotinic acid, an important building block for the synthesis of modern insecticides. J Ferment Bioeng 1994; 77: 382-5.

22. Nagasawa T, Hurh B, Yamane T. Production of 6-hydroxynicotinic acid from nicotinic acid by resting cells of Pseudomonas fluorescens TN5. Biosci Biotechnol Biochem 1994; 58: 665-8.

23. Yoshida T, Nagasawa T. Enzymatic functionalization of aromatic $N$-heterocycles: hydroxylation and carboxylation. J Biosci Bioeng 2000; 89: 111-8.

24. Wang SN, Xu P, Tang HZ, Meng J, Liu XL, Ma CQ. “Green" route to 6-hydroxy-3-succinoyl-pyridine from $(S)$ nicotine of tobacco waste by whole cells of a Pseudomonas sp. Environ Sci Technol 2005; 39: 6877-80.

25. Garrett MD, Scott R, Sheldrake GN, Dalton H, Goode P. Biotransformation of substituted pyridines with dioxygenase-containing microorganisms. Org Biomol Chem 2006; 4: 2710-5.

26. Nomura Y, Harashima S, Oshima Y. A simple method for detection of enzyme activities involved in the initial step of phthalate degradation in microorganisms. J Ferment Bioeng 1989; 67: 291-6.
27. Woo TH, Cheng AF, Ling JM. An application of a simple method for the preparation of bacterial DNA. Biotechniques 1992; 13: 696-8.

28. Maniatis T, Fritsch EF, Sambrook J. Molecular cloning: a Laboratory Manual. Cold Spring Harbor, NY: Cold Spring Harbor Laboratory. 1982.

29. Sharma RC, Schimke RT. Preparation of electrocompetent $E$. coli using salt-free growth medium. Biotechniques 1996; 20: 42-4.

30. Altschul SF, Gish W, Miller W, Myers EW, Lipman DJ. Basic local alignment search tool. J Mol Biol 1990; 215: 403-10.

31. Gorelenkov V, Antipov A, Lejnine S, Daraselia N, Yuryev A. Set of novel tools for PCR primer design. Biotechniques 2001; 31: 1326-30.

32. Saitou N, Nei M. The neighbour-joining method: a new method for reconstructing phylogenetic trees. Mol Biol Evol 1987; 4: 406-25.

33. Zuckerkandl E, Pauling L. Evolutionary divergence and convergence in proteins, pp. 97-166 in Evolving Genes and Proteins, edited by V. Bryson and H. J. Vogel. Academic Press, New York. 1965.

34. Tamura K, Peterson D, Peterson N, Stecher G, Nei M, Kumar S. MEGA5: Molecular evolutionary genetics analysis using maximum likelihood, evolutionary distance, and maximum parsimony methods. Mol Biol Evol. 2011.

35. Choi KY, Kim D, Sul WJ, Chae J-C, Zylstra GJ, Kim YM, Kim E. Molecular and biochemical analysis of phthalate and terephthalate degradation by Rhodococcus sp. strain DK17. FEMS Microbiol Lett 2005; 252: 207-13.

36. Tomás-Gallardo L, Canosa I, Santero E, Camafeita E, Calvo E, López JA, Floriano B. Proteomic and transcriptional characterization of aromatic degradation pathways in Rhodoccocus sp. strain TFB. Proteomics 2006; 6: 119-32.

37. Stingley RL, Brezna B, Khan AA, Cerniglia CE. Novel organization of genes in a phthalate degradation operon of Mycobacterium vanbaalenii PYR-1. Microbiol 2004; 150: 3749-61.

38. Kallimanis A, Labutti KM, Lapidus A, Clum A, Lykidis A, Mavromatis K, Pagani I, Liolios K, Ivanova N, Goodwin L, Pitluck S, Chen A, Palaniappan K, Markowitz V, Bristow J, Velentzas AD, Perisynakis A, Ouzounis CC, Kyrpides NC, Koukkou AI, Drainas C. Complete genome sequence of Arthrobacter phenanthrenivorans type strain (Sphe3). Stand Genomic Sci 2011; 4: 123-30.

39. Patrauchan MA, Florizone C, Dosanjh M, Mohn WW, Davies J, Eltis LD. Catabolism of benzoate and phthalate in Rhodococcus sp. strain RHA1: redundancies and convergence. J Bacteriol 2005; 187: 4050-63.

40. Taylor BF, King CA. Phthalic acid and pyridine dicarboxylic acids as catabolic analogs. FEMS Microbiol Lett 1987; 44: 401-5. 
Rūta Stanislauskienè, Mark Rudenkov, Laimonas Karvelis,

Renata Gasparavičiūtè, Rita Meškienė, Vida Časaitė,

Rolandas Meškys

FTALIO RŪGŠTIES SKAIDYMO OPERONO IŠ

ARTHROBACTER SP. 68B ANALIZE்

\section{Santrauka}

68b bakterinis kamienas buvo išskirtas iš užteršto dirvožemio. Remiantis $16 \mathrm{~S}$ rDNR analize, jis priklauso Arthrobacter genčiai. Šis kamienas sugeba panaudoti ftalio rūgštị kaip vienintelị anglies šaltinį - tai buvo įrodyta fiziologiniais ir biocheminiais metodais. Nustatyta, kad Arthrobacter sp. 68b ląstelès sugeba panaudoti ftalio rūgštị arba modifikuoti chinolino rūgští, jei bakterijos buvo kultivuotos terpèje su ftalio rūgštimi. Nagrinèjant iš dalies nustatyto genomo seką, buvo aptiktas galimas ftalio rūgšties skaidymo operonas (pht), kurị sudaro aštuoni genai, septyni iš jų dalyvauja ftalio rūgšties skaidyme iki protokatechuato. Nustatyta, kad prieš pht operoną yra galimos ftalato esterio hidrolazès genas (pehA). Visi operono genai buvo individualiai padauginti PGR metodu ir nustatytos ju sekos. Sekoskaitos rezultatai visiškai atitiko de novo gautas sekas. Genų homologų paieškos rezultatai rodo, kad visų genų produktai yra panašiausi ị kitų Arthrobacter genties kamienų ftalio rūgšties degradacijos baltymus, ir patvirtino, kad 68b kamienas ftalio rūgštị verčia iki protokatechuato 3,4-dioksigenazės būdu.

Raktažodžiai: Arthrobacter sp., ftalio rūgštis, 3,4-ftalato dioksigenazé, chinolininè rūgštis 